\title{
Somatic embryogenesis in ferns: a new experimental system
}

\author{
Anna Mikuła $\cdot$ Mariusz Pożoga $\cdot$ Karolina Tomiczak $\cdot$ \\ Jan J. Rybczyński
}

Received: 2 September 2014/Revised: 16 December 2014/ Accepted: 6 January 2015 / Published online: 20 January 2015

(C) The Author(s) 2015. This article is published with open access at Springerlink.com

\begin{abstract}
Key message Somatic embryogenesis has never been reported in ferns. The study showed that it is much easier to evoke the acquisition and expression of embryogenic competence in ferns than in spermatophytes.

Abstract We discovered that the tree fern Cyathea delgadii offers an effective model for the reproducible and rapid formation of somatic embryos on hormone-free medium. Our study provides cyto-morphological evidence for the single cell origin and development of somatic embryos. Somatic embryogenesis (SE) in both primary and secondary explants was induced on half-strength microand macro-nutrients Murashige and Skoog medium without the application of exogenous plant growth regulators, in darkness. The early stage of SE was characterized by sequential perpendicular cell divisions of an individual epidermal cell of etiolated stipe explant. These resulted in the formation of a linear pro-embryo. Later their development resembled that of the zygotic embryo. We defined three morphogenetic stages of fern somatic embryo development: linear, early and late embryonic leaf stage. The transition from somatic embryo to juvenile sporophyte was quick and proceeded without interruption caused by dormancy. Following 9 weeks of culture the efficiency of somatic embryogenesis reached 12-13 embryos per responding explant. Spontaneous formation of somatic embryos and callus production, which improved the
\end{abstract}

Communicated by X. S. Zhang.

A. Mikuła $(\bowtie) \cdot$ M. Pożoga · K. Tomiczak · J. J. Rybczyński Polish Academy of Sciences Botanical Garden, Center for Biological Diversity Conservation in Powsin, Prawdziwka 2, 02-973 Warsaw, Poland

e-mail: amikula@obpan.pl effectiveness of the process sevenfold in 10-month-long culture, occurred without subculturing. The tendency for $C$. delgadii to propagate by SE in vitro makes this species an excellent model for studies relating to asexual embryogenesis and the endogenous hormonal regulation of that process and opens new avenues of experimentation.

Keywords Cyathea delgadii . Hormone-free medium . Light microscopy $\cdot$ Methyl salicylate $\cdot$ Somatic embryo . Tree fern
Abbreviations
PGRs Plant growth regulators
SE Somatic embryogenesis
1/ Medium containing half-strength Murashige and
2MS Skoog micro- and macro-nutrients

\section{Introduction}

Somatic embryogenesis is the developmental pathway by which plant somatic cells develop into somatic embryos. Apart from the lack of syngamy, these resemble zygotic embryos. SE is currently used to propagate hundreds of species of seed plant in vitro, and forms the basis of fundamental studies that help us understand how a single somatic cell develops to form an entire plant (Vogel 2005). The process serves as a model system for the study of molecular, biochemical and physiological events that occur during both the induction and the development of the embryo. Although SE was discovered more than half a century ago (Steward et al. 1958), our entire knowledge of this process is based on seed plants. It has not previously 
been reported for monilophytes. Moreover, it has been reported only twice for cryptogams, and in each case these were lycopods, i.e. Lycopodiella inundata (L.) Holub (Atmane et al. 2000) and Huperzia selago (L.) Bernh. Ex Schrank and Mart. [Lycopodium selago L.] (Szypuła et al. 2005). Since ferns and spermatophytes are sister lineages (Pryer et al. 2001), ferns are useful subjects for developmental and morphological research, comparative evolution, and functional genomics (Johnson and Renzaglia 2008, 2009; Der et al. 2011; Tomescu 2011; Vasco et al. 2013). They can also help to improve our understanding of SE.

In terms of zygotic embryogenesis, ferns have been relatively under-investigated compared to spermatophytes. Extensive studies of the sexual reproduction of ferns were conducted at the turn of the twentieth century and a considerable amount of information regarding the embryology of this plant group was collected, collated and published by Wardlaw (1955). He demonstrated the pattern of development that occurred during the early embryology of various fern species and how the two-celled early embryo of leptosporangiate ferns underwent six additional regular divisions to create an eight-celled embryo. The proliferation of zygotic initial cells eventually led to a four-part embryo, the four quadrants forming the root, leaf, foot, and shoot apex, respectively, that would later produce additional vegetative organs. Subsequently, morphological, cytological, and biochemical studies conducted on fern zygotic embryos at various stages of development were summarized by DeMaggo (1977). Since that time, progress has not been as rapid or as extensive in its scope, and there still remains a dearth of embryological information relating to those processes that follow on from cell and organ differentiation. By contrast, there is a wealth of information available relating to the developmental anatomy and morphology of shoot, leaf and root of the fern sporophyte (White and Turner 1995). Currently, researchers aim for a better understanding of the evolution of land plants, and alternation of generations, as observed in ferns (Niklas and Kutschera 2009; Ligrone et al. 2012). Johnson and Renzaglia $(2008,2009)$ elucidated the development of the embryo and gametophyte placenta for the fern model Ceratopteris richardii Brongn. and significantly broadened our knowledge of the development of the fern zygotic embryo. It was also shown that auxin is involved in the initial zygotic cell division of Marsilea vestita Hook. \& Grev. and organization of body plan in fern sporophytes (Poli 2005).

In addition to the sexual life cycle, some fern species undergo asexual development resulting in the formation of sporophytes from gametophyte somatic cells (apogamy) (Raghavan 1989). Either obligate or induced apogamy is considered equivalent to organogenesis of sporophytes (Raghavan 1989; Fernández et al. 1996; Gabancho et al.
2010). An apogamous system of reproduction occurs both in nature and in vitro, and it has been regularly studied ever since its discovery by Farlow (1874) up to the present time (Cordle et al. 2011). This method of reproduction became established in fern lineages that experienced frequent reticulate evolution in combination with polyploidy and has been recognized for approximately $10 \%$ of extant ferns (Liu et al. 2012). However, apogamy has been only sporadically reported for tree fern species (Stokey 1918; Parajuli and Joshi 2014).

Propagation of tree fern species is a difficult challenge and thus, few tree ferns are propagated by commercial nurseries. Some of the species can be propagated by spores, but they cannot be propagated vegetatively as they do not produce offsets from their 'trunk' (Large and Braggins 2004). However, for commercial purposes, the erect 'trunk' of tree ferns (e.g. Dicksonia antarctica Labill.) can be cut, transported and replanted, and can still continue to grow, as long as the crown remains intact (FPA Biodiversity Program 2012). Over the last few years, the propagation of tree fern species from spores has become the priority area for ex situ conservation studies (Simabukuro et al. 1998a, b; Arens 2001; Hiendlmeyer and Randi 2007; Rechenmacher et al. 2010; Ranil et al. 2011; Martíez et al. 2014). Conversely, methods of in vitro culture have been exploited for the propagation of tree ferns by gametophyte multiplication and sporophyte regeneration. Media used for growth and proliferation of gametophytes were either supplemented with plant growth regulators (PGRs) (Bonomo et al. 2013; Das et al. 2013) or not (Goller and Rybczyński 1995, 2007; Kuriyama et al. 2004; Khare et al. 2005; Moura et al. 2012). The application of biotechnology methods for tree ferns was summarized by Rybczyński and Mikuła (2011). Their list of 20 species has recently been extended by at least 3 new taxa, namely: Alsophila odonelliana (Alston) Lehnert, Cyathea gigantea (Wall. ex. Hook.) and C. cunninghamii Hook. f. (Moura et al. 2012; Bonomo et al. 2013; Das et al. 2013). Gametophytes cultured in vitro also provide sufficient plant material for cryo-studies and the long-term preservation of tree ferns in liquid nitrogen (Mikuła et al. 2011a). Further methods are required for the efficient, quick and effective propagation of tree fern species in vitro.

The present work relates to Cyathea delgadii Sternb., a species of evergreen, non-seasonal tree fern (10 m tall) native to the gallery, montane, cloud, and rain forests of the Caribbean, Central and South America, including valuable ecoregions of the Atlantic Forest. It grows at an elevation of 100-2,730 m above sea level (Oliveira-Filho and Ratter 1995). Cyathea delgadii is a member of a large complex centered on Cyathea fulva (M. Martens \& Galeotti) Fée (Arens 2001). It produces spores all the year round (some 300 million spores per frond), but their viability, like the 
spores of most species belonging to family Cyatheaceae, diminishes after a few weeks of storage at room temperature or after a 2-year period of storage at $4{ }^{\circ} \mathrm{C}$ (Simabukuro et al. 1998a). This species is cultivated as a garden ornamental plant (Hiendlmeyer and Randi 2007).

Our study focuses on the induction and description of $\mathrm{SE}$ in the fern $C$. delgadii, belonging to a group of plants (Monilophyta) for which this phenomenon has not yet been reported. Emphasis is focused on cyto-morphological evidence for SE induction, embryo development, and the efficiency of this process during short- and long-term culture.

\section{Materials and methods}

\section{Plant material}

Laminae of $C$. delgadii fronds were collected from a plant growing in the greenhouse of the PAS Botanical GardenCBDC, Warsaw, Poland. They were dried at room temperature for 5 days to liberate spores. The released spores were surface sterilized by wrapping sporangia in Whatman no. 1 filter paper and immersing the package in $70 \%$ (v/v) ethanol for $30 \mathrm{~s}$ and in $5 \%(\mathrm{v} / \mathrm{v})$ commercial bleach (Domestos) for $20 \mathrm{~min}$ and then washing the package three times in sterile distilled water. After disinfection, spores were blotted onto medium containing half-strength MS micro- and macronutrients (Murashige and Skoog 1962) with full complement of vitamins (1/2MS), $2 \%(\mathrm{w} / \mathrm{v})$ sucrose and $0.7 \%(\mathrm{w} / \mathrm{v})$ plant agar. The $\mathrm{pH}$ of the medium was adjusted to 5.8 before autoclaving at $120^{\circ} \mathrm{C}$ for $20 \mathrm{~min}$. The spores germinated at $22 \pm 1{ }^{\circ} \mathrm{C}$ under a $16 / 8 \mathrm{~h}$ photoperiod, at a light intensity of $3.5 \mu \mathrm{E} \mathrm{m}^{-2} \mathrm{~s}^{-1}$. The young gametophytes were transferred separately onto fresh 1/2MS medium and subcultured only once. They were maintained in subculture until they reached maturity. After spontaneous syngamy, zygotic embryos and young sporophytes were produced after 1 year of gametophyte culture.

Somatic embryogenesis induction and the assessment of its efficiency

Stipes of zygotic embryo-derived sporophytes (Fig. 1a) developed under $16 / 8 \mathrm{~h}$ photoperiod were used for the initiation of primary SE. Secondary SE was induced on intact somatic embryos that had reached the first crozier stage and on the stipes of somatic embryo-derived sporophytes (Fig. 1b) that had developed 2 or 3 fronds, growing in darkness. The plant material was cultured on 1/2MS agar medium supplemented with $2 \%(\mathrm{w} / \mathrm{v})$ sucrose and $0.7 \%$ (w/v) plant agar. The cultures were kept in a climatic chamber at $+22 \pm 2{ }^{\circ} \mathrm{C}$, in constant darkness, and at a relative humidity of $35-55 \%$.

The percentage of responding explants and the number of somatic embryos per responding explant was calculated after 9 weeks of culture. Subsequent evaluations were carried out every month for almost 1 year of culture. The somatic embryo production capacity index (SEPCI) was calculated by multiplying the proliferation percentage by
Fig. 1 Details of origin of plant material used for culture initiation. a A young zygotic embryo-derived sporophyte showing the first two fronds, which were used as a source of primary explants. b A young somatic embryo-derived etiolated sporophyte showing the first two fronds, which were used as a source of secondary explants. Bracket shows an initial explant. $G$ gametophyte, $R$ adventitious root, $S A$ shoot apex, $1 s t$ first frond, $2 n d$ second frond
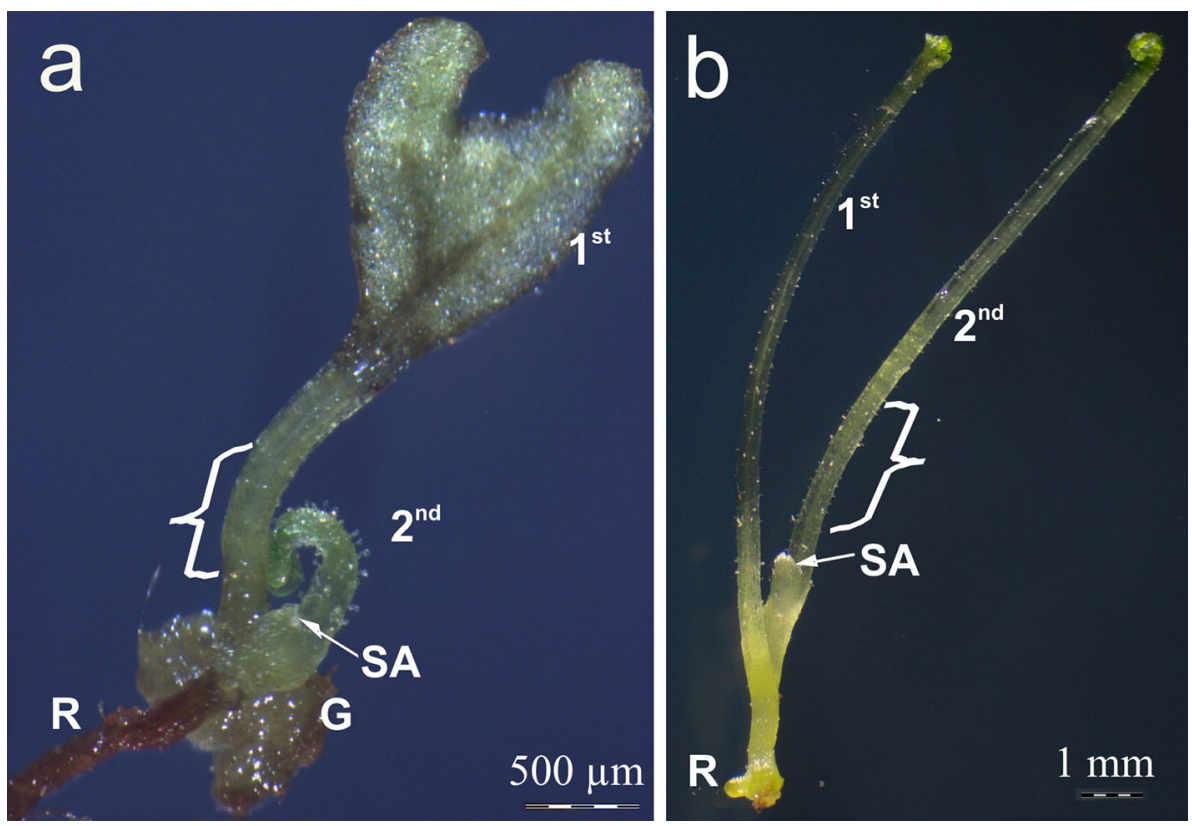
the number of somatic embryos formed per explant and then dividing the result by 100 .

Sporophyte acclimatization and transfer to soil

For acclimatization, sporophytes cultured under $16 / 8$ h photoperiod conditions were used. Sporophytes with 4-6 fronds were transferred to pots of peat and perlite (3:1) substrate, and kept in mini greenhouses. The potting mixture was autoclaved at $121{ }^{\circ} \mathrm{C}$ for $20 \mathrm{~min}$. The mini greenhouses were lightly ventilated daily, and the sporophytes periodically misted for 4-6 weeks. The plantlets were then transferred to a greenhouse.

\section{Microscopic preparation}

Stipes of somatic embryo-derived sporophytes were fixed in $2 \%$ glutaraldehyde in $0.1 \mathrm{M}$ cacodylate buffer $(\mathrm{pH} 7.2)$ at room temperature for $2 \mathrm{~h}$, rinsed three times with $0.1 \mathrm{M}$ cacodylate buffer ( $\mathrm{pH} 7.2$ ), and post-fixed with $2 \% \mathrm{OsO}_{4}$ (osmium tetroxide) at $4{ }^{\circ} \mathrm{C}$ overnight. After rinsing in $0.1 \mathrm{M}$ cacodylate buffer, explants were dehydrated in a graded ethanol series $(30 \rightarrow 50 \rightarrow 70 \rightarrow 90 \rightarrow 96 \rightarrow 99.8 \%)$, followed by mixtures of absolute ethanol and propylene oxide $(3: 1 ; 1: 1 ; 1: 3)$, and finally, propylene oxide. Explants were then embedded in Epon-Spurr epoxy resin mixture. Twomicrometre-thick sections were cut using an LKB ultramicrotome (Sweden) and stained for several seconds with aqueous $0.1 \%$ toluidine blue solution. They were examined using a Vanox epifluorescence microscope (Olympus, Japan) equipped with a computer image analysis system (cellSens Standard ver. 1.7). To detect the natural red autofluorescence of chlorophyll, a blue-violet light (BV filter: $400-440 \mathrm{~nm}$ ) was used.

For examination of the first few divisions of epidermal cells, plant material was fixed in FAA (5 parts formaldehyde:5 parts glacial acetic acid:90 parts ethanol) overnight and then dehydrated in graded ethanol solutions (70, 80 and $100 \%$ ). Next, explants were cleared in methyl salicylate as described by Young et al. (1979) and examined under a Vanox microscope (Olympus, Japan) using blue-violet light (BV filter: $400-440 \mathrm{~nm}$ ).

\section{Statistical analysis}

Results were analyzed by means of a one-way ANOVA analysis of variance and Fisher's least significant difference (LSD) procedure using Statgraphics Plus software. Significance was set at the 0.05 level. The results were expressed as the mean \pm standard deviation based on three independent experiments, each consisting of at least 30 explants.
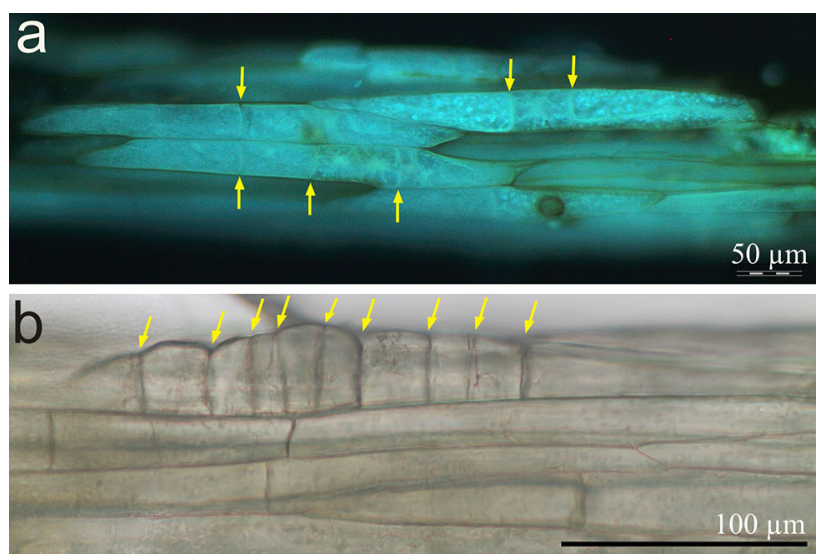

Fig. 2 Early epidermal cell divisions of stipe explants cultured on hormone-free medium in darkness (explant cleared in methyl salicylate). a Three epidermal cells after one, two or three cell divisions perpendicular to the polar axis of the stipe following 2 weeks culture (BV filter: $400-440 \mathrm{~nm}$ ). b Ten-celled linear somatic pro-embryo originating from a single epidermal cell of stipe explant. Yellow arrows show cell walls (color figure online)

Fig. 3 Light microscopy evidence for somatic embryo origin and development in Cyathea delgadii. a Numerous pro-embryos following several anticlinal, periclinal and inclined cell divisions of single epidermal cells of stipe explant cultured on hormone-free medium, in darkness. b Four-segmented somatic pro-embryo developed directly on the surface of stipe. c Trichomes located on one side of immature, multicellular somatic embryo. d Differentiation of the embryonic leaf (arrow). e A somatic embryo showing the first leaf and primordium of the second leaf (squashed specimen). f Junction between somatic embryo and initial stipe explant showing epidermal origin of embryo (semi-thin section stained with toluidine blue). g Longitudinal section of well-developed somatic embryo showing the first leaf, shoot apex and primordium of the second leaf, as well as transverse section of the stipe explant; 6 weeks of culture (arrows indicate amyloplasts). h Numerous somatic embryos with first leaf after 6 weeks growth. i Partly green, differentiated lamina of the first leaf of juvenile sporophyte. j Somatic embryo-derived young sporophyte showing extended lamina of primary frond and primordium of second leaf, as well as two roots, following development in the presence of light. $C$ cortex, $E p$ epidermal cells, $L$ first leaf, $R$ root, $S A$ shoot apex, $T$ trichomes, $V c$ axial cylinder (color figure online)

\section{Results}

Production of zygotic embryo-derived sporophytes as a source of primary explants

Propagated gametophytes of $C$. delgadii achieved maturity within a year of in vitro culture on 1/2MS medium. Further details of sex organ formation for the species were provided by Rybczyński and Mikuła (2011). Following fertilization, the early development of the zygotic embryo was confined to the archegonium. Within 4-5 weeks, the main organographic regions had been determined. Subsequently, the first leaf elongated and the second developed (Fig. 1a). The stipes of the first young fronds, grown at a photoperiod of $16 / 8 \mathrm{~h}$, were used for the following experiments (Fig. 1a). 

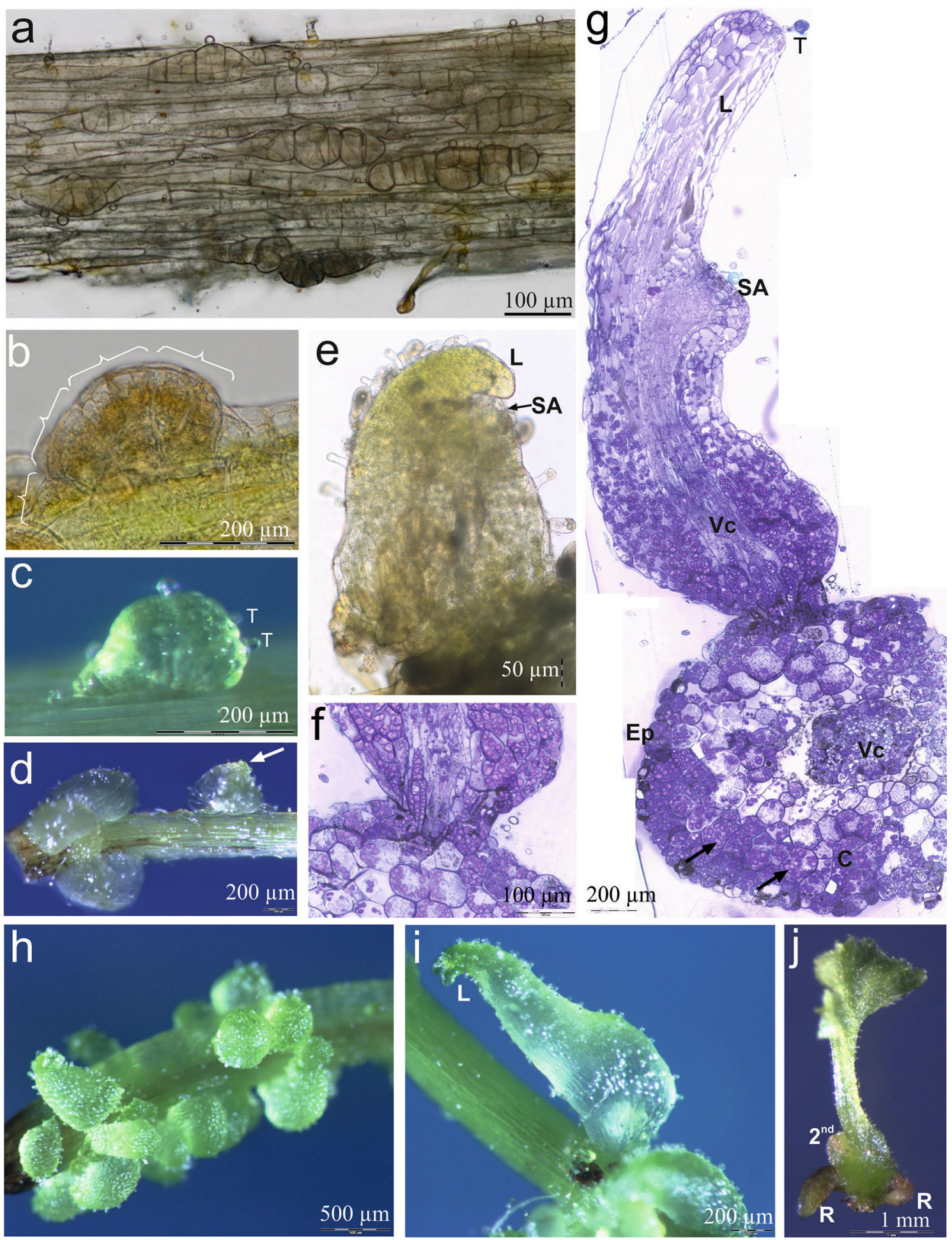

Cyto-morphological evidence for somatic embryogenesis induction and embryo development

Within 2 weeks following culture initiation, divisions of epidermal cells of stipe explants began (Fig. 2a). The first division of the epidermal cell was perpendicular to the polar axis of the explant and led to the formation of two, almost equal or unequal daughter cells. The next few divisions (divisions 8-10) were also perpendicular to the stipe axis (Fig. 2b). Within 3 weeks of culture, these 
divisions resulted in the formation of linear somatic proembryos.

Dividing epidermal cells were widely distributed along the explants (Fig. 3a). Within 3 weeks following culture initiation, numerous epidermal cells of stipe explants were present, resulting from several anticlinal, periclinal and inclined cell divisions. These irregular divisions led to the formation of four separate and unequally sized segments of the pro-embryo (Fig. 3b). During the early stage of somatic embryo development, trichomes developed on two of four of the visible segments of the pro-embryo (Fig. 3c). Further development of somatic embryos focused on the differentiation of the embryonic leaf (Fig. 3d). Later, the emerging lamina primordium of the first frond and primordium of the shoot apex were visible (Fig. 3e).

Histological analysis revealed that the somatic embryos originated directly from epidermal cells of stipe explants (Fig. 3f, g). The structure of the stipe was maintained for the entire duration of the initial culture on 1/2MS medium. The single-layered epidermis, cortex and closely arranged axial cylinder cells of explants were clearly distinguishable, even after 6 weeks of culture (Fig. 3g). The majority of the epidermal and cortex cells were rich in amyloplasts, which stained intensely with toluidine blue. The axial cylinder appeared to be structurally intact. During the first leaf stage, the somatic embryos showed a normally developed vascular system and the first leaf, shoot apex and the primordium of the second leaf were also visible (Fig. 3g). On some explants, all the somatic embryos produced during the first 6 weeks of culture were almost at the same stage of development (Fig. 3h).

Somatic embryos which developed in darkness were opaque (Fig. 3h) or somewhat translucent at the base (Fig. 3d), but apically, were white, yellow or greenish in color. At transition from embryo to juvenile sporophyte, the lamina of the embryonic leaf became pale green during the next week of culture, and the whole leaf elongated (Fig. 3i). The next step of sporophyte development was the formation of the second frond and the elongation of the root. On returning to light, the frond lamina of the etiolated sporophyte quickly became dark green and regained its typical shape (Fig. 3j).

The efficiency of somatic embryogenesis in short- and long-term culture

When stipes of the first frond of zygotic embryos were cultured on 1/2MS agar medium containing $2 \%$ sucrose, primary somatic embryos were formed at a frequency of $19.3 \%$ over a 9 week period (Fig. 4). When SE was induced in stipes of somatic embryo-derived juvenile sporophytes, $85.71 \%$ of explants formed new somatic embryos. In intact somatic embryos, the percentage of

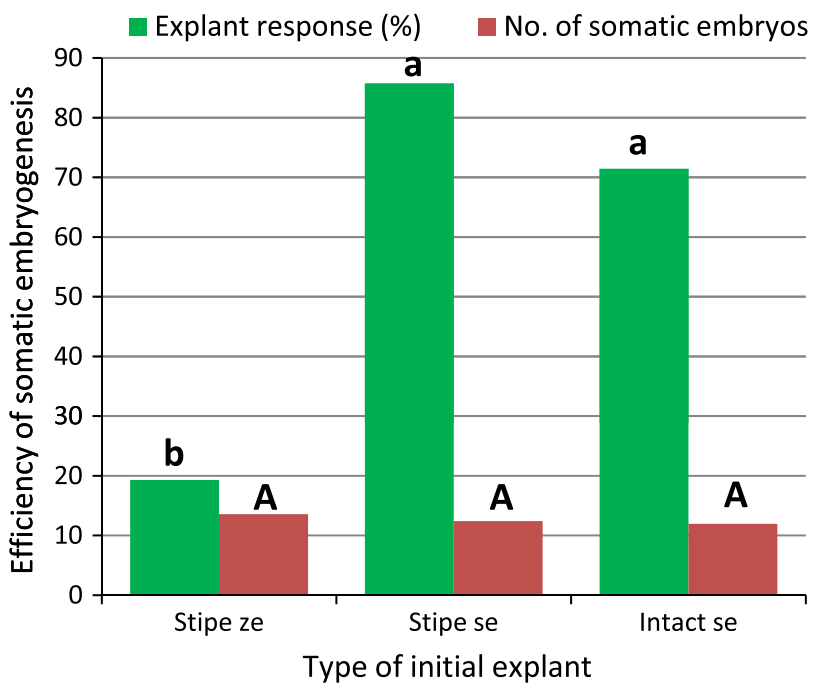

Fig. 4 Efficiency of somatic embryogenesis induced for both zygotic and somatic embryo-derived explants following 9 weeks of culture in the dark. Medium 1/2MS supplemented with $2 \%(\mathrm{w} / \mathrm{v})$ sucrose. $z e$ zygotic embryo developed under photoperiod conditions, se somatic embryo developed in darkness

responding explants was lower $(71.43 \%)$, but the difference was statistically insignificant. The average number of somatic embryos produced was similar for each type of initial explant studied, ranging from 11.97 to 13.57 per stipe (Fig. 4).

Somatic embryo-derived stipe explants were able to produce somatic embryos within 11 months of maintenance on $1 / 2 \mathrm{MS}$ medium supplemented with $2 \%$ sucrose without any subculture. The cultures were kept constantly in darkness. The frequency of explants producing somatic embryos ranged between 61.0 and $86.4 \%$ (Table 1). The efficiency of $C$. delgadii SE in long-term culture differed significantly (Table 1). After 2 months, each stipe produced 13.2 somatic embryos. The embryogenic potential increased gradually, reaching 84.3 and 80.1 somatic embryos per responding explant by the end of months 9 and 10, respectively. The efficiency of SE decreased to 55.2 embryos per stipe after 11 months of continuous culture. The highest SEPCI index was based on 10-monthold cultures.

The progress of an 11-month-old culture maintained in darkness is shown in Fig. 5. The fronds of somatic embryoderived sporophytes gradually elongated, and the mass of tissue was seen to increase (Fig. 5a-c). After 3 months of culture, mass-produced young sporophytes (Fig. 5d) developed two fronds and one or two roots (see Fig. 1b). After 5 months, the fronds possessed long stipes and most of their laminae remained as croziers (Fig. 5e). A few of these commenced further development (Fig. 5e). After 7 months of culture, the first symptoms of sporophyte aging were observed. Some fronds turned brown (Fig. 5f). 
Table 1 Efficiency of Cyathea delgadii somatic embryogenesis during 11 months of culture on 1/2MS medium supplemented with $2 \%$ sucrose, without any subculture, in darkness

\begin{tabular}{llll}
\hline $\begin{array}{l}\text { Month of } \\
\text { culture }\end{array}$ & $\begin{array}{l}\text { Percentage of responding } \\
\text { explants }\end{array}$ & $\begin{array}{l}\text { No. of somatic embryos per responding } \\
\text { explant }\end{array}$ & $\begin{array}{l}\text { Somatic embryo production capacity index } \\
\text { (SEPCI) }\end{array}$ \\
\hline 2 & $80.5 \pm 3.9 \mathrm{ab}$ & $13.2 \pm 3.6 \mathrm{~d}$ & 10.6 \\
5 & $74.2 \pm 18.2 \mathrm{ab}$ & $26.1 \pm 10.6 \mathrm{~cd}$ & 19.4 \\
6 & $82.0 \pm 19.4 \mathrm{ab}$ & $34.3 \pm 18.2 \mathrm{c}$ & 28.1 \\
7 & $61.0 \pm 10.4 \mathrm{~b}$ & $54.8 \pm 46.4 \mathrm{~b}$ & 33.4 \\
8 & $61.9 \pm 26.1 \mathrm{~b}$ & $58.3 \pm 43.8 \mathrm{~b}$ & 36.1 \\
9 & $68.9 \pm 18.5 \mathrm{ab}$ & $\mathbf{8 4 . 3} \pm \mathbf{4 4 . 7 a}$ & $\mathbf{5 8 . 1}$ \\
10 & $\mathbf{8 6 . 4} \pm \mathbf{1 0 . 8 a}$ & $\mathbf{8 0 . 1} \pm \mathbf{5 3 . 0 a}$ & $\mathbf{6 9 . 2}$ \\
11 & $64.3 \pm 14.6 \mathrm{~b}$ & $55.2 \pm 44.5 \mathrm{~b}$ & 35.5 \\
\hline
\end{tabular}

Values marked with the same letter do not differ significantly at the 0.05 level according to Fisher's least significant difference (LSD's) test. Data represent mean \pm standard deviation of three experiments, each consisting of at least 30 explants

Bold values indicate best results

During 11 months of extended culture, some fronds died (Fig. 5c).

The aging fronds spontaneously produced new somatic embryos directly on their laminae and stipes (Fig. 5f, g). These somatic embryos were capable of further development without any subculture (Fig. 5g). Alternative ways of embryo formation were also investigated. When cultures were maintained in darkness for at least 5 months, brown tissue was formed at the base of sporophytes (Fig. 5e). During the next 3 months, somatic embryos arose from this tissue (Fig. 5h). Moreover, the laminae and stipes of aging fronds developed embryogenic callus tissue (Fig. 5i, j). The resultant somatic embryos were also able to develop into sporophytes (Fig. 5k). Under 16/8 h photoperiod conditions, all etiolated sporophytes turned green and developed normally to form plantlets (Fig. 51). Sporophytes began to produce spores after 6 months of growing under ex vitro conditions. The process of SE for C. delgadii is shown schematically in Fig. 6. It commences with spores, passes through the gametophyte stage, the induction of zygotic and somatic embryogenesis, the growth of mature plantlets and their acclimatization to ex vitro conditions, and ends with a second generation of spores (Fig. 6).

\section{Plant regeneration and acclimatization}

After 3 weeks of culture of initial explants, embryos were formed (Fig. 3a). Most of these had the capacity for further development. Under conditions of constant darkness, embryos developed a few roots and fronds, but the latter remained at the crozier stage for several months (Fig. 5d, e). When a 3-week-old initial culture was subjected to photoperiod conditions, the embryos expanded sequentially and developed into sporophytes without any additional subculture (Fig. 51). The sporophytes grew quickly and, within 8 months, their acclimatization to ex vitro conditions was complete. Following acclimatization, 23 of the 25 tested sporophytes survived and were transferred to a greenhouse. During the next 6 months, the sporophytes grew to maturity. They produced spores that were able to germinate and form fertile gametophytes (Fig. 6).

\section{Discussion}

In this paper, we report on a novel SE experimental system for ferns. Our aim was to pioneer a new line of research into this process. This we accomplished by investigating a species of the Monilophyta clade. We discovered that epidermal cells of $C$. delgadii stipe explants have the potential to initiate somatic embryo development equal to that of many spermatophytes. However, it is much easier to evoke the acquisition and expression of embryogenic capacity of somatic cells in ferns than in spermatophytes. This study has enabled us to develop an effective, reproducible and rapid method of propagating $C$. delgadii sporophytes. Furthermore, the method of cultivation presented here is particularly attractive in that the use of exogenous PGRs is not required.

Somatic versus zygotic embryogenesis in ferns

Species belonging to Cyatheaceae, like most leptosporangiate ferns, exhibit a type of embryology in which the first zygotic division is transverse to the polar axis of the gametophyte and longitudinal to the axis of the archegonium (Johnson and Renzaglia 2009). According to Wardlaw (1955) this first division is slightly asymmetric in Pteris serratula L.f. and Marsilea. The following two divisions give rise to a 4-celled zygotic embryo. Contrary to reports of typical leptosporangiate fern zygotic 

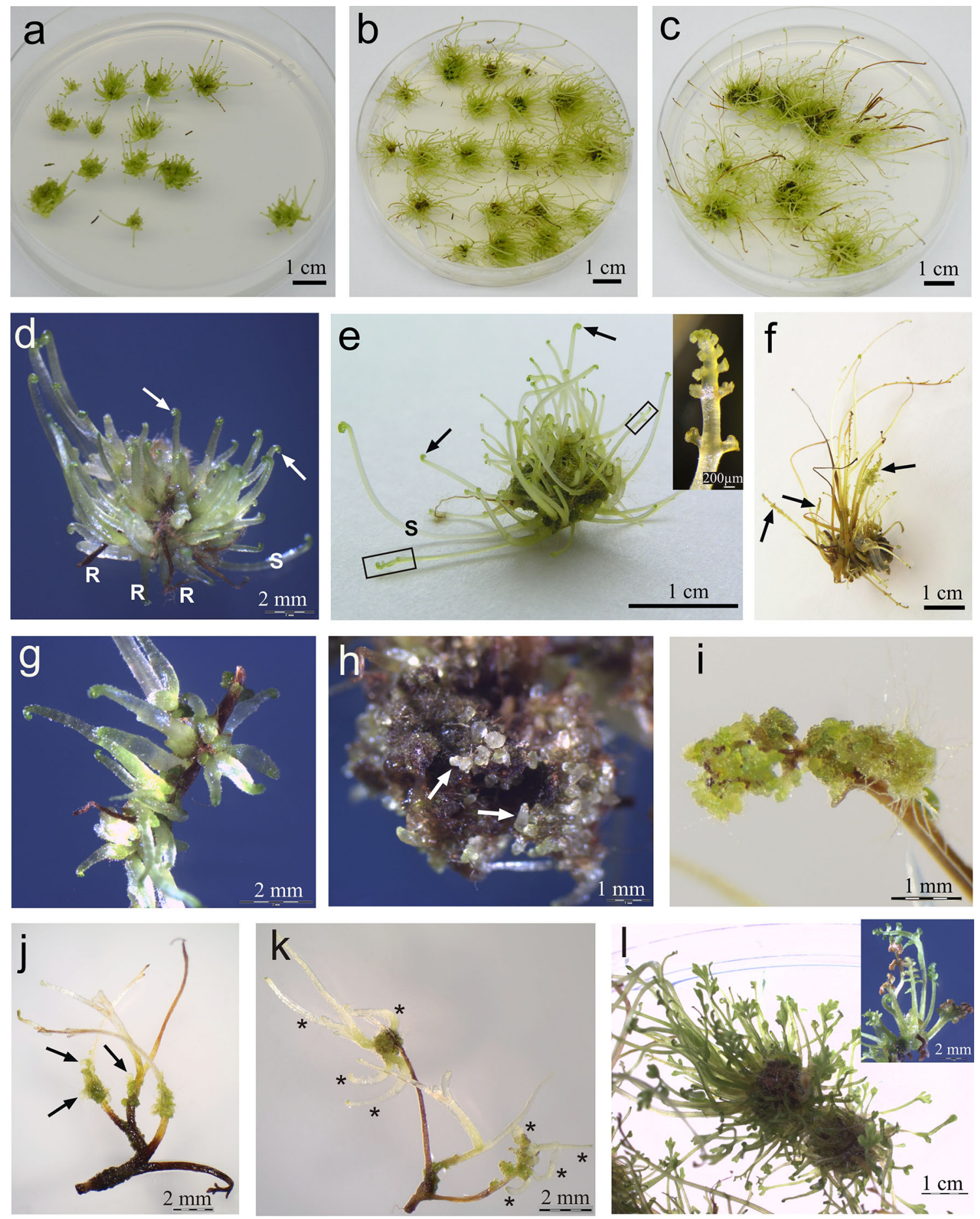

Fig. 5 Progress of somatic embryo production in Cyathea delgadii during long-term culture. General view of a culture maintained in darkness for: a 3 months, b 5 months, c and 11 months. d Numerous young sporophytes with roots and croziers (arrows), after 3 months. e Typical fronds with long stipes and croziers (arrows), with brown tissue at their bases; a few laminae that have developed further (rectangle and small picture), after 5 months. f Spontaneous production of somatic embryos on aging fronds (arrows), after 7 months. g Further development of spontaneously induced somatic embryos. h Somatic embryos derived from the brown tissue (arrows), after 8 months. i Yellow and green callus on surface of lamina. $\mathbf{j}$ Yellow and green callus on surface of stipes with differentiated somatic embryos (arrows). k Young sporophytes (asterisks) formed by secondary, spontaneous somatic embryogenesis. I Image of sporophytes after 2 week-long light exposure. $R$ root, $S$ stipe (color figure online) 


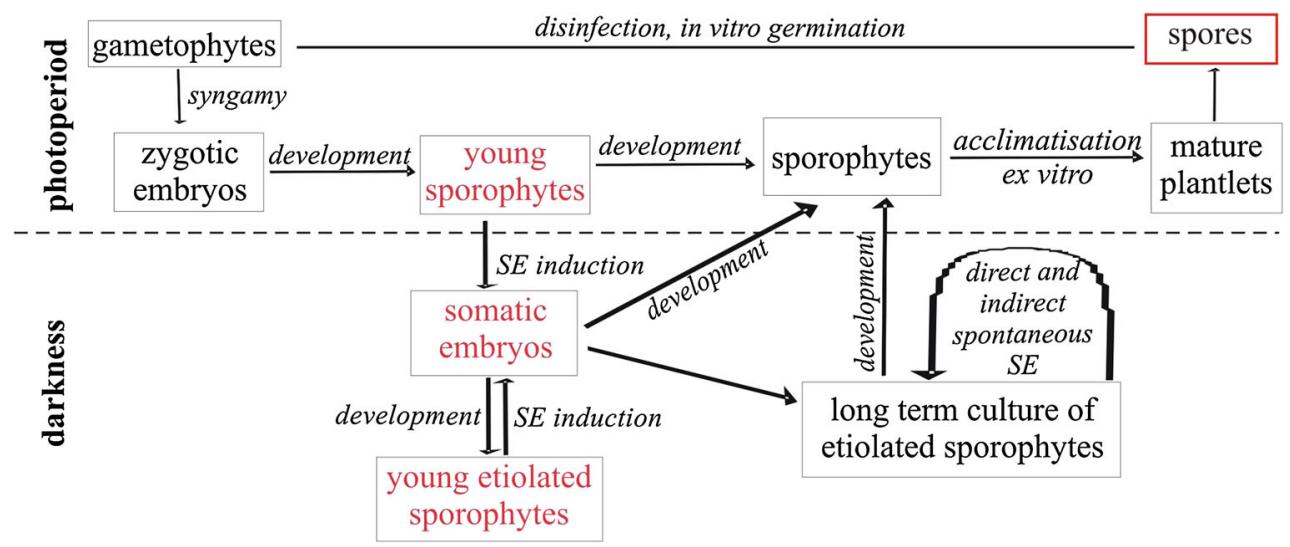

Fig. 6 Schematic diagram representing the course of the newly described somatic embryogenesis process for $C$. delgadii: commencing with spores, passing through the gametophyte stage, followed by induction of zygotic and somatic embryogenesis and finally, the production of mature plantlets initially grown in vitro and later under ex vitro conditions. $S E$ somatic embryogenesis, initial explants are shown in red (color figure online)

lack of an archegonium and adjacent gametophyte tissue able to supply nutrients and growth-regulating substances (e.g. auxins) to the developing zygotic embryo (DeMaggo 1977), the polarity of $C$. delgadii somatic embryos was established very early. This forms the subject of a future investigation.

Developmental differences between embryo-derived and apogamous sporophyte

The development of $C$. delgadii somatic embryo and juvenile sporophyte was similar to that observed during the zygotic embryogenesis of other leptosporangiate ferns (Wardlaw 1955). Likewise, the first embryonic leaf differed from subsequently formed leaves, and an embryonic root was formed at the base of the first leaf. Development of an apogamous sporophyte differs from the development of an embryo-derived sporophyte in certain details. It was shown that the young apogamous sporophytes of Asplenium auritum Sw., A. monodon Liebm., Phegopteris connectilis (Michx.) Watt. and Pteris multifida Poir. did not form roots in parallel to the first leaf (Kawakami et al. 1995; Soare et al. 2007; Gabancho et al. 2010). Moreover, the first sporophyte leaf possessed stomata, multicellular glandular hairs, and scales (Gabancho et al. 2010). Contrary to the first leaf of the apogamous sporophyte, the juvenile, embryonic leaf of $C$. delgadii did not develop stomata.

C. delgadii somatic embryogenesis versus somatic embryogenesis of seed plants and lycopods

Propagation of spermatophytes in in vitro culture by SE is a complicated process requiring the proper combination of 
various factors such as: type of plant material, PGRs, sugars, light, mineral salts, etc. (Gaj 2004). For the majority of seed plant species, exogenous PGRs are amongst the most important factors involved in the induction and maintenance of SE (Raemakers et al. 1995; Fehér et al. 2003). Our studies showed that SE in both primary and secondary explants of the fern $C$. delgadii can be induced without the application of PGRs. Moreover, spontaneous formation of somatic embryos and callus production, which improved the effectiveness of the process several fold in 10-month-long culture, occurred without subculturing. This suggests that the juvenile, etiolated stipe explant that was used for culture initiation and a starvation play a crucial role in SE induction in $C$. delgadii. We do not know of any other species for which the process of SE is so highly effective, yet demands so little effort. It is possible that the low margin requirement in the culture may be specific for cryptogamic plants. In the lycopod Lycopodiella inundata, the nodular callus and somatic embryo production were established on a MS medium with half-strength mineral salt content, but supplemented with PGRs (Atmane et al. 2000). For a second species of lycopod, Huperzia selago, both the induction of callus and the formation of nodular structures on its surface and their subsequent development into somatic embryos occurred on MS hormone-free medium containing an identical mineral salt concentration to that used for $C$. delgadii (Szypuła et al. 2005).

For some species, non-hormonal factors, for example, osmotic shock, drought, mechanical wounding of tissues, macro-salts, heavy metal ions and heat or cold shock, can also be used to induce or enhance SE efficiency (Smith and Krikorian 1989; Choi et al. 1998a; Patnaik et al. 2005; You et al. 2007; Mikuła et al. 2011b). Our study showed that in the case of $C$. delgadii, none of the aforementioned inducers (even mechanical damage) are essential to regain cell totipotency and to acquire the competence necessary to convert somatic cells to embryogenic cells. Our success was probably due to the use of a specific type of explant, i.e. a piece of very young etiolated sporophyte, and maintaining the initial culture in constant darkness. It would appear that endogenous hormone levels in cells and tissues of this species are a major factor in determining cellular response. Choi and Soh (1996) showed that direct somatic embryo formation from ginseng zygotic embryos grown on regulator-free medium was related to the excision of zygotic embryos and polar endogenous auxin accumulation. Conversely, the origin of somatic embryos as multiple or single-state forms, depends on the degree of maturity of the plant material used for experiments (Maheswaran and Williams 1985; Choi et al. 1998b). We have produced somatic embryos of single-cell origin from the maturing epidermis of juvenile sporophyte stipes of $\mathrm{C}$. delgadii. According to Maheswaran and Williams (1985), this type of tissue can contain some immature epidermal cells and these single cells are capable of embryogenic response.

\section{Embryo development}

It is well known in pteridophyte embryology that the patterns of zygotic embryo development are defined by the plane of zygotic division and the direction in which the first leaf and shoot apical meristem grow with respect to the gametophyte (Wardlaw 1955; Johnson and Renzaglia 2009). However, in comparison to spermatophytes, the studies of fern embryo development are still incomplete and the developmental stages have not yet been given names. We demonstrated how the pivotal phases of $C$. delgadii somatic embryo formation have morphological counterparts in fern zygotic embryogenesis. Leptosporangiate fern embryos have no suspensor, whereas this is present both in zygotic and most of somatic embryos of seed plants (Young 1995). Instead, during the first stage of fern embryo formation, the foot plays a crucial absorptive and nutritional role in the growth of the embryo (Johnson and Renzaglia 2008). However, using current methods for plant body investigations, we were not able to recognize a foot in the somatic embryos of $C$. delgadii. In future, we intend to use transmission electron microscopy to provide an anatomical framework for studies of somatic embryogenesis.

Another important issue is the designation of morphogenetic stages of the fern embryo, in which the basic structure of the embryo is established. In angiosperms, the development of both zygotic and somatic embryos occurs via the globular, heart, torpedo and cotyledonary stages (Young 1995; Filonova et al. 2000). The sequence of gymnosperm embryo development can be divided into three phases: proembryogeny (up to suspensor elongation), early embryogeny (up to the root meristem establishment) and late embryogeny (including establishment of the root and shoot meristems) (Filonova et al. 2000). At present, we are able only to define three different morphogenetic stages representing three major events in the development of somatic embryo in ferns:

1. linear stage: from the first cell division until the formation of several-celled pro-embryo (Figs. 2, 3a, b);

2. early embryonic leaf stage: until the emergence of the first leaf (Fig. 3c, d);

3. late embryonic leaf stage: until the emergence of the second leaf primordium (Fig. 3e, g, h).

Although the earliest stage of somatic embryo development in $C$. delgadii, comparable to globular stage was 
not observed, the subsequent developmental patterns appeared to correspond to those observed during the zygotic embryogenesis of leptosporangiate ferns (Wardlaw 1955; Johnson and Renzaglia 2008). The fern zygotic embryo grows and develops its first leaf without any interruption caused by dormancy until it emerges from the gametophytic tissue and becomes established as a freeliving sporophyte (Wardlaw 1955). Similarly, the development of the somatic embryo into a juvenile sporophyte is rapid and proceeds directly under the light conditions stated for the tree fern $C$. delgadii.

\section{Conclusions}

Ferns, as a group, are the closest living relatives of spermatophytes, and are of interest not only because of their ornamental value, but also for their usefulness as models for evolutionary, morphological and developmental studies. The phylogenetic position of ferns and their amenability to apogamic reproduction both in vivo and in vitro make them valuable models for studying how asexual plant embryogenesis evolved. The simple, effective and hormone-free system of SE induction described for $C$. delgadii can help broaden our fundamental knowledge of this process. Looking to the future, it also provides an excellent model for the study of endogenous hormonal regulation of SE. This novel method for the in vitro reproduction of tree ferns may also be valuable for the rapid and mass propagation of these plants both for conservation and commercial purposes.

Author contribution statement The authors have made the following declarations regarding their contributions: Conceived and designed the experiments: AM. Performed the experiments: AM, MP, KT. Analyzed the data: AM, JJR. Contributed reagents/materials/analysis tools: AM. Contributed to the writing of the manuscript: AM, JJR, KT.

Acknowledgments We thank Prof. Mieczysław Kuraś (University of Warsaw) for his help during microscopic analysis. This research was supported by the Polish National Center for Science (NCN), No. 2011/03/B/NZ9/02472.

Conflict of interest The authors declare that they have no conflict of interest.

Open Access This article is distributed under the terms of the Creative Commons Attribution License which permits any use, distribution, and reproduction in any medium, provided the original author(s) and the source are credited.

\section{References}

Arens NC (2001) Variation in performance of the tree-fern Cyathea caracasana (Cyatheaceae) across a successional mosaic in an Andean cloud forest. Am J Bot 88:545-551
Atmane N, Blervacq AS, Michaux-Ferriere N, Vasseur J (2000) Histological analysis of indirect somatic embryogenesis in the Marsh clubmoss Lycopodiella inundata (L.) Holub (Pteridophytes). Plant Sci 156:159-167

Bonomo MC, Martínez OG, Tanco ME, Cardozo R, Avilés Z (2013) Spores germination and gametophytes of Alsophila odonelliana (Cyatheaceae) in different sterile media. YTON 82:119-126

Choi YE, Soh WY (1996) Effect of plumule and radicle on somatic embryogenesis in the cultures of ginseng zygotic embryos. Plant Cell Tissue Org Cult 45:137-143

Choi YE, Yang DC, Choi KT (1998a) Induction of somatic embryos by macrosalt stress from mature zygotic embryos of Panax ginseng. Plant Cell Tissue Org Cult 52:177-181

Choi YE, Yang DC, Park JC, Soh WY, Choi KT (1998b) Regenerative ability of somatic single and multiple embryos from cotyledons of Korean ginseng on hormone-free medium. Plant Cell Rep 17:544-551

Cordle AR, Bui LT, Irish EE, Cheng C-L (2011) Laboratory-induced apogamy and apospory in Ceratopteris richardii. In: Fernández H, Kumar A, Revilla MA (eds) Working with ferns: issues and applications. Springer Science + Business Media, LLC, New York, pp 25-36

Das S, Choudhury MD, Mazumder PB (2013) In vitro propagation of Cyathea gigantea (Wall ex. Hook): a tree-fern. Int J Recent Sci Res 4:221-224

DeMaggo AE (1977) Cytological aspects of reproduction in ferns. Bot Rev 43:427-448

Der JP, Barker MS, Wickett NJ, DePamphilis CW, Wolf PG (2011) De novo characterization of the gametophyte transcriptome in bracken fern, Pteridium aquilinum. BMC Genomics 12:99

Farlow WG (1874) An asexual growth from the prothallus of Pteris cretica. Q J Microsc Sci 14:266-272

Fehér A, Pasternak TP, Dudits D (2003) Transition of somatic plant cells to an embryogenic state. Plant Cell Tiss Org Cult 74:201-228

Fernández H, Bertrand AM, Sánchez-Tamés R (1996) Influence of tissue culture conditions on apogamy in Dryopteris affinis sp. affinis. Plant Cell Tiss Org Cult 45:93-97

Filonova LH, Bozhakov PV, von Arnold S (2000) Developmental pathway of somatic embryogenesis in Picea abies as revealed by time-lapse tracking. J Exp Bot 51:249-264

FPA Biodiversity Program (2012) Tree-fern management plan for the sustainable harvesting, transporting or trading of Dicksonia antarctica in Tasmania 2012. http://laptop.deh.gov.au/biodiver sity/wildlife-trade/sources/management-plans/tas-treefern.html

Gabancho LR, Prada C, Galán JMGY (2010) Sexuality and apogamy in the Cuban Asplenium auritum-monodon complex (Aspleniaceae). Plant Syst Evol 289:137-146

Gaj M (2004) Factors influencing somatic embryogenesis induction and plant regeneration with particular reference to Arabidopsis thaliana (L.) Heynh. Plant Growth Reg 43:27-47

Goller K, Rybczyński JJ (1995) In vitro culture used for woody fern Cyathea australis (R. Br.) Domin vegetative propagation. Acta Soc Bot Pol 64:13-17

Goller K, Rybczyński JJ (2007) Gametophyte and sporophyte of treeferns in vitro culture. Acta Soc Bot Pol 76:193-199

Hiendlmeyer R, Randi AM (2007) Response of spores and young gametophytes of Cyathea delgadii Sternb. (Cyatheaceae) and Blechnum brasiliense Desv. (Blechnaceae) to different light levels. Acta Bot Bras 21:909-915

Jayasekera RDE, Bell PR (1959) The effects of various experimental treatments on the development of the embryo of the fern Thelypteris palustris. Planta 54:1-14

Johnson GP, Renzaglia KS (2008) Embryology of Ceratopteris richardii (Pteridaceae, tribe Ceratopterideae), with emphasis on placental development. J Plant Res 121:581-592 
Johnson GP, Renzaglia KS (2009) Evaluating the diversity of pteridophyte embryology in the light of recent phylogenetic analyses leads to new inferences on character evolution. Plant Syst Evol 283:149-164

Kawakami SM, Ito M, Kawakami S (1995) Apogamous sporophyte formation in a fern Pteris multifida and its characteristics. J Plant Res 108:181-184

Khare PB, Behera SK, Srivastava R, Shukla SP (2005) Studies on reproductive biology of a threatened tree-fern, Cyathea spinulosa Wall. ex Hook. Curr Sci India 89:173-177

Kuriyama A, Kobayashi T, Maeda M (2004) Production of sporophytic plants of Cyathea lepifera, a tree-fern, from in vitro cultured gametophyte. J Jpn Soc Hortic Sci 73:140-142

Large MF, Braggins JE (2004) Tree-ferns. Timber Press, Cambridge, pp 1-359

Ligrone R, Duckett JG, Renzaglia KS (2012) Major transitions in the evolution of early land plants: a bryological perspective. Ann Bot 109:851-871

Liu H-M, Dyer RJ, Guo Z-Y, Meng Z, Li J-H, Schneider H (2012) The evolutionary dynamics of apomixis in ferns: a case study from polystichoid ferns. J Bot 2012:1-11

Maheswaran G, Williams EG (1985) Origin and development of somatic embryoids formed directly on immature embryos of Trifolium repens in vitro. Ann Bot 56:619-630

Martíez OG, Tanco ME, Prada C, Guerra R (2014) Gametophytic phase of Alsophila odonelliana (Cyatheaceae). Nord J Bot 32:92-97

Mikuła A, Makowski D, Walters C, Rybczyński JJ (2011a) Exploration of cryo-methods to preserve tree and herbaceous fern gametophytes. In: Fernández H, Kumar A, Revilla MA (eds) Working with ferns: issues and applications. Springer Science + Business Media, New York Dordrecht Heidelberg London, pp 173-192

Mikuła A, Tomiczak K, Rybczyński JJ (2011b) Cryopreservation enhances embryogenic capacity of Gentiana cruciata (L.) suspension culture and maintains (epi)genetic uniformity of regenerants. Plant Cell Rep 30:565-574

Moura IR, Simões-Costa MC, Garcia J, Silva MJ, Duarte MC (2012) In vitro culture of tree-fern spores from Cyatheaceae and Dicksoniaceae families. Acta Hortic 937:445-461

Murashige T, Skoog F (1962) A revised medium for rapid growth and bioassays with tobacco tissue cultures. Physiol Plant 15:473-497

Niklas KJ, Kutschera U (2009) The evolutionary development of plant body plans. Funct Plant Biol 36:682-695

Oliveira-Filho AT, Ratter JA (1995) A study of the origin of central Brazilian forests by the analysis of plant species distribution patterns. Edinb J Bot 52:141-194

Parajuli J, Joshi SD (2014) In vitro study of effects of growth hormones on sporophyte development of Cyathea spinulosa. Int J Biodivers Conserv 6:247-255

Patnaik D, Mahalakshmi A, Khurana P (2005) Effect of water stress and heavy metals on induction of somatic embryogenesis in wheat leaf base cultures. Ind J Exp Biol 43:740-745

Poli DB (2005) The role of auxin on the evolution of embryo development and axis formation in land plants. Dissertation, University of Maryland, pp 1-199

Pryer KM, Schneider H, Smith AR, Cranfill R, Wolf PG, Hunt JS, Sipes SD (2001) Horsetails and ferns are a monophyletic group and the closest living relatives to seed plants. Nature 409:619-622

Raemakers CJJM, Jacobsen E, Visser RGF (1995) Secondary somatic embryogenesis and applications in plant breeding. Euphytica 81:93-107
Raghavan V (1989) Developmental biology of fern gametophytes. Cambridge University Press, Cambridge, pp 259-295

Ranil RHG, Pushpakumara DKNG, Janssen T, Fraser-Jenkins CR, Wijesundara DSA (2011) Conservation priorities for tree-ferns (Cyatheaceae) in Sri Lanka. Taiwania 56:201-209

Rechenmacher CA, Schmitt JLB, Droste A (2010) Spore germination and gametophyte development of Cyathea atrovirens (Langsd. \& Fisch.) Domin (Cyatheaceae) under different $\mathrm{pH}$ conditions. Braz J Biol 70:1155-1160

Rybczyński J, Mikuła A (2011) Tree ferns biotechnology: from spores to sporophytes. In: Fernández H, Kumar A, Revilla MA (eds) Working with ferns: issues and applications. Springer Science + Business Media, New York Dordrecht Heidelberg London, pp 135-147

Simabukuro EA, De Carvalho MAM, Felippe GM (1998a) Reserve substances and storage of Cyathea delgadii Sternb. spores. Rev Bras Bot 21:149-152

Simabukuro EA, Dyer AF, Felippe GM (1998b) The effect of sterilization and storage conditions on the viability of the spores of Cyathea delgadii. Am Fern J 88:72-80

Smith DL, Krikorian AD (1989) Release of somatic embryogenic potential from excised zygotic embryos of carrot and maintenance of proembryonic cultures in hormone-free medium. Am J Bot 76:1832-1843

Soare LC, Vişoiu E, Andrei M (2007) Researches concerning the in vitro differentiation of the fern Phegopteris connectilis (Michx.) Watt. Notul Bot Hort Agrobot Cluj-Napoca Inst 35(1):7-14

Steward FC, Mapes MO, Smith J (1958) Growth and organized development of cultured cells. I. Growth and division of freely suspended cells. Am J Bot 45:693-703

Stokey AG (1918) Apogamy in the Cyatheaceae. Bot Gaz 65:97-102

Stone IG (1958) The gametophyte and embryo of Polyphlebium venosum (R. Br.) Copeland (Hymenophyllaceae). Aust J Bot 6:183-203

Szypuła W, Pietrosiuk A, Suchocki P, Olszowska O, Furmanowa M, Kazimierska O (2005) Somatic embryogenesis and in vitro culture of Huperzia selago shoots as a potential source of huperzine A. Plant Sci 168:1443-1452

Tomescu AMF (2011) The sporophytes of seed-free vascular plants: major vegetative developmental features and molecular genetic pathways. In: Fernández H, Kumar A, Revilla MA (eds) Working with ferns: issues and applications. Springer Science + Business Media, New York Dordrecht Heidelberg London, pp 67-96

Vasco A, Moran RC, Ambrose BA (2013) The evolution, morphology, and development of fern leaves. Front Plant Sci 4:345

Vogel G (2005) How does a single somatic cell become a whole plant. Science 309:86

Wardlaw CV (1955) Embryogenesis in plants. Wiley and Sons Inc, New York, pp 142-170

White RA, Turner MD (1995) Anatomy and development of the fern sporophyte. Bot Rev 61:281-305

You XL, Han JY, Choi YE (2007) Plant regeneration via direct somatic embryogenesis in Panax japonicus. Plant Biotechnol Rep 1:5-9

Young EC (1995) Structural and developmental patterns in somatic embryogenesis. In: Thorpe TA (ed) In Vitro embryogenesis in plants. Kluwer Academic Publishers, Dordrecht, pp 205-247

Young BA, Sherwood RT, Bashaw EC (1979) Cleared-pistil and thick-sectioning techniques for detecting aposporous apomixis in grasses. Can J Bot 57:1668-1672 